\title{
Chapter 3 Attention Speculation and Political Bubbles
}

\subsection{The Mediatized Society}

We live in an increasingly mediatized world. Mediatization refers to the tendency of societal institutions to be more and more dependent on the media and adapt themselves to its conventions and to media logic (Hjarvad 2008). In a mediatized society, the media veritably establish the conditions for social interactions and relationships, commerce and marketing, science and debate, and activism and politics. When political activists protest or organize a demonstration in order to send a political message, it is essential to get media coverage. The message must be heard by people and parties other than the activists themselves. There is no point in "Occupying Wall Street" unless documented and disseminated. Mediatization provides social and political actors with a strong incentive to act according to the media's precepts.

In the mediatized society, it is key to deliver material to the media for the good story which will hit the agenda right way. Politics is mediatized when political actors such as cabinet executives, ministers, members, spin doctors, and press officers tailor their communication - and sometimes even their politics and legislation - to the news media's criteria for the good story. If the news media align their criteria to the commercial interests, the result may become, at its most garish, that entertainment value becomes the real ideal of news coverage. 
Mediatization has been seen as a symptom of the increasing power of the media. Not only do they set the agenda; their criteria for doing so spread to other institutions and actors as incentives to subjugate to their media logic. Mediatized politics has been characterized as politics that has lost its autonomy and independence relating to the media (Mazzoleni and Schulz 1999: p. 250).

The media logic may also be used to take back power from the media when the politicians adapt to it and use its structure and dynamics to their own advantage (Thesen 2013). This is what political spin is all about. The ploy does not necessarily include gaining mastery of the scene on a commercial media market, selling entertaining, riotous, and spectacular stories. It may also play on journalism's professional virtues like the noble invocation to report from the inner circles of power and let the public in on the end game going on behind closed doors. Planned tactical "leaks" may, for instance, be employed to play the journalists in this regard and set the agenda to one's benefit.

Alas, the consequence of politicians spinning the media too efficiently to their own end may be the emergence of a media-created political reality detached from the real world and its problems.

\subsection{The Media-Created Political Reality}

The media may not just cover the political reality; they may partake in creating it. When that happens, it may be seen as a symptom of what the late French philosopher Jean Baudrillard called hyperreality. Here, the divide between media and reality implodes, and what goes for "reality" becomes a media product or a simulation of reality which is impossible to discern from the real thing (Baudrillard 1994). Fiction may acquire such a marked influence on reality that the distinction between facts and fiction, between news and entertainment, gets blurred. Or, as the Danish satirical Nihilistic People's Party described it back in 2010: 
The entire political reality is a media-created illusion the politicians maintain in order to hide the fact that the project of Enlightenment ended in Dancing With the Stars. ${ }^{1}$

This way of putting it does not seem overly absurd anymore, nor does Baudrillard's philosophy seem that radical. One case in point is how an episode of the world famous Danish TV series Borgen thematizing prostitution was used as political leverage for a bill to decriminalize prostitution in the real Borgen, the Danish Parliament at Christiansborg. Or worse: Trump's fabled way into American politics.

\subsection{Where Was Obama Born?}

Donald Trump admitted at long last on September 16, 2016, that former US President Barack Obama was rightfully an American citizen. Prior to that date, Trump had for years advanced an argument, later turned into an extensive conspiracy theory, to the effect that Obama not being born in the USA, not being an American citizen for real, couldn't legitimately hold the Presidency. It was virtually this crazed claim and debacle that marked Trump's entrance into American politics.

What fostered these speculations was the fact that Obama's father was an economist in Kenya, which was taken to show that Kenya, and not Hawaii, had to be Obama's true birthplace. Another story had it that Obama at one point acquired Indonesian citizenship and lost his American citizenship in the process. And then there was the story of how dodgy it surely seems that Barack Obama's middle name is Hussein.

For years Trump sat at the conspirational hearth and refrained from shutting down the rumor about Obama's foreign citizenship. He actually boasted that it was he who forced Obama to prove in 2011 to be rightfully American by

\footnotetext{
${ }^{1}$ Vass, T. \& Vestergaard, M. (2010): Nihilistisk Folkeparti [Nihilistic People's Party], front cover. Verified June 24, 2017: http://www.nihilistisk-folkeparti.dk
} 


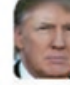

\section{Donald J. Trump}

2. Follow

An 'extremely credible source' has called my office and told me that @BarackObama's birth certificate is a fraud.

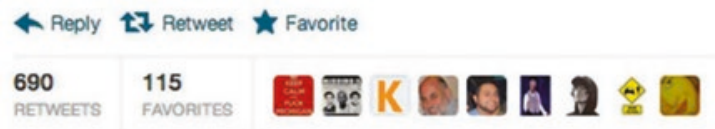

4.23 PM - 6 Aug 12 - Embed this Tweet

FIG. 3.1. A tweet from Donald Trump in 2012 after Obama had presented his birth certificate, and the "birther" case against Obama continued.

showing his birth certificate. That, in turn, had some people doubt the veracity of the document, and a new conspiracy theory was born (Fig. 3.1).

But then something happened: While Trump refused to acknowledge the sitting President Obama's American nationality, the Trump campaign may have started to realize that the birther case was not a strong case. Trump then admitted that President Obama was indeed an American citizen but at the same time claimed that the rumor originally was set to sea by Hillary Clinton's presidential campaign back in 2008 when Clinton and Obama competed internally to win the Democrats over. Trump also managed to frame his backing down in such a manner that it sounded as if he was doing Americans and Obama himself a huge favor by finally dropping the birther business.

Over the years, this case has enjoyed a lot of attention, even though it turned out to be false. Trump managed for a time to benefit from the fact that entertainment value is a decisive news criterion in a commercialized media market. On The Daily Show in 2013, John Oliver called upon Trump 
to run for President for the fun of it. Oliver has since lived to regret it. ${ }^{2}$

Not all politics is like that. All the same, politics is not entirely above the delicate and quite dangerous problem the mediatization has created: Politics may move further and further away from reality and facts with all their inherent complexities. The citizens lose out in the long run if the negative consequences of policies and legislation are ignored politically or if attempts are made to hide them from the public, other politicians, and the media.

If politics is all about winning the horse race and voter maximization, reality may lose out. One would think that politics is supposed to solve real problems. It should be considered a victory to ensure, say, that less environmental damage is caused, independently of whether more or less support for the political party comes along with this triumph. If there is no ambition to solve real problems, then politics is reduced to showbiz and speculation in sending, creating, or struggling over political signals and symbols.

\subsection{Signal Legislation and Symbol Politics}

The context is different, but "signal legislation" are bills:

1. Whose primary goal is to signal a specific point of view

2. Proposed with no real interest in the consequences

3. Often, with no interest in the real scope of the problem (Elholm 2011)

Signal legislation has the potential for political speculation as it is immune to, and detached from, what other experts or science might have to say. The point is not about the facts, the particulars, or calculating the consequences of a legislation

\footnotetext{
${ }^{2}$ THR Staff (2016): "John Oliver Regrets Begging Donald Trump to Run for President," The Hollywood Reporter, November 7, 2016. Verified June 10, 2017: http://www.hollywoodreporter.com/news/ john-oliver-donald-trump-president-944682
} 
but simply the signal it sends. You signal your point of view. When fact-finding is not a concern, the legislative process may be carried out that much faster without commissions, committees, or other forms of investigative bodies: Fast process, fast signaling of political determination, trustworthiness, initiative, and dynamism. And, as Elholm points out:

The success criterion for signal policies is pure genius. The results of the legislation are secondary. The purpose of the law has been reached as soon as the signals are received, or perhaps even when they have been sent! ${ }^{3}$

No matter how comfortable signal policies and legislation may seem, they come at a cost. The lack of calculating the consequences may mean a whole array of measures are taken that are futile at best and may have unintended social, economic, or administrative consequences. Arguing for signal policies often requires a grasp of the majority's sense of justice, opinions, set of values, or sentiments, and those are hardly as clear-cut as the rhetorics would often have it. Additionally, such signals may cause a polarization between those whose opinions the signals suit and those who are stigmatized or outraged by the very same signal. Finally, focus and resources are taken away from more substantial efforts to come up with concrete, effectual solutions to societal issues through legislation and policies. Signal legislation is the fast, easy, or tactical political reaction that does not necessarily lead to the durable, efficacious, or sustainable solution.

A case in point is the veiling ban passed in Denmark. Generally speaking, the ban applies to all forms of covering your face in public space. In other words, the ban does not specifically address religious veiling. Nevertheless, the Danish foreign minister was less diplomatic and more blatant in a statement that he posted on his Facebook profile. In the statement, he makes it clear that the ban is aimed directly at niqab and burka, combating the "dark men" that are responsible for the oppression of women symbolized by garments

${ }^{3}$ Elholm (2011: p. 170). 
that cover their faces. ${ }^{4}$ But already before the ban, Danish legislation allowed for sentencing an individual to prison for up to 4 years, if that somebody is forcing another to cover his or her face. ${ }^{5}$

Signal legislation is often carried out without much consideration for the actual scope of the problem the law is addressing. Thus, the last investigation of the use of burka and niqab in Denmark executed in 2009 reveals that as few as 100-200 individuals are actually wearing such garments. About $50 \%$ of them have converted to Islam. ${ }^{6}$

At the same time, Denmark is not showing any interest in the effect of a similar law implemented in France in 2011. According to the findings of sociologist Agnés de Féo, the French veiling ban has been counterproductive rather than beneficial to integration. The women who nowadays are fully covering their face started doing so after the implementation of the law. And women who fully covered their face prior to the implementation of the veiling ban are no longer leaving home. ${ }^{7}$ Those kinds of investigations and evaluations of actual impacts are of no concern to the politician who is pressing for legislation of purely symbolic value. Jonathan Laurence, Professor of Political Science at Boston College and expert in Muslim communities in Europe, says it tellingly:

I don't think policymakers would pay such studies any mind since these laws are never about integration effects. ${ }^{8}$

\footnotetext{
${ }^{4}$ Samuelsen, A. (2017). Facebook, October 6, 2017 (Danish), verified December 2, 2017: https:/www.facebook.com/AndersSamuelsenLA/ posts/10156454217557366

${ }^{5}$ https://www.retsinformation.dk/eli/ft/200912L00181

6"Rapport om brugen af niqap og burka"(2009). Verifiziert 02.12.2017: https://www.e-pages.dk/ku/322/html5/

${ }^{7}$ Taylor, A. (2016). "Banning burqas isn't a sensible response to terrorism," Washington Post, 12.08.2016, verified 26.06.2018: https://www. washingtonpost.com/news/worldviews/wp/2016/08/12/banning-burqasisnt-a-sensible-response-to-terrorism/?utm_term $=.8283 \mathrm{~b} 0 \mathrm{~b} 0 \mathrm{bde} 5$ ${ }^{8}$ Ibid.
} 


\section{Denmark wants to seize jewelry and cash from refugees:}

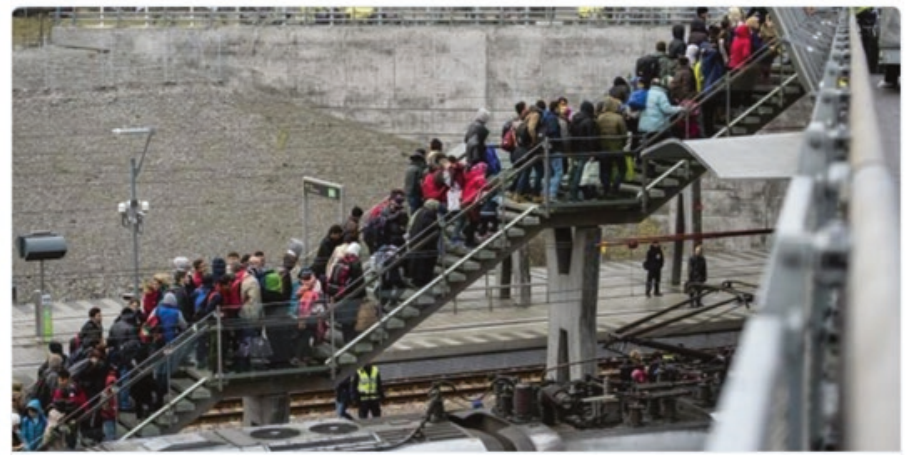

Denmark wants to seize jewelry and cash from refugees

The law "has been branded petty and cruel."

washingtonpost.com

\section{1:35 AM - 18 Dec 2015}

\section{Retweets 8 Likes}

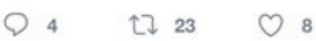

FIG. 3.2. The Danish "jewelry law" went worldwide and made headlines in international media like The Washington Post.

Signal legislation is a close cousin to politics of symbolism, which also is more about showing vigor than actually solving problems. A case in point is Danish legislation dubbed the "jewelry law" that was enacted in early 2016 (Fig. 3.2).

An entire immigration law package was passed, but it was the call for the confiscation of refugees' possessions that got the bulk of the attention, both nationally and internationally. The attention was of negative nature. It fueled outrage.

When push came to shove, the warrant to confiscate possessions was only utilized four times during the first year the law was in force. However, other parts of the law package that did not get much attention had significant consequences. L87, 
of which the "jewelry law" forms a part, entails that certain refugee groups have to wait up to 3 years before they may even file for a family reunification, let alone have their loved ones actually joining them. The time limits established by international conventions are bent to their extreme. Be that as it may, not a lot of fuss was made pertaining to this part when the law package was passed and later enacted in its entirety. ${ }^{9}$

If political signals and symbolic messages are often most proposed with scarce interest for their effects and the real scope or nature of the societal issue, then why send them at all? Because they serve an entirely different purpose. Years ago, the influential political scientist Murray Edelman put it this way: They may condense a whole political, ideological, or cultural narrative in a very simple manifestation, because:

Condensation symbols evoke emotions bound to the situation. In a symbolic incident or action, they condense patriotic pride, worries, memories of yesteryear's victories or humiliations, promises of future grandeur; some of these or all of these simultaneously. ${ }^{10}$

Signal legislation and symbol politics are ways to speculate in the attention market to create political bubbles.

\subsection{Political Bubbles}

Speculative bubbles emerge now and again on financial markets. Fairly recent examples are the housing bubble bursting in 2008 causing the financial crisis and the dot.com bubble around the arrival of the millennium. History offers a list of financial bubbles, dating all the way back to the first documented, speculative bubble: the Dutch tulip bulb bubble in

\footnotetext{
${ }^{9}$ Olsen, T.L. (2017). "Et år med omstridt smykkelov: Politiet har brugt den fire gange" DR.dk January 16, 2017. Verified May 9, 2017: https:// www.dr.dk/nyheder/politik/et-aar-med-omstridt-smykkelov-politiethar-brugt-den-fire-gange

${ }^{10}$ Edelman (1979: p. 847).
} 
1636-1637 (Brunnermeier and Schnabel 2017). When financial bubbles emerge, they are often driven by stories of huge monetary gains waiting ahead, accompanied with narratives to the effect that this time around, it will be different than the previous bubbles after which investors and speculators suffered great losses when the bust came (Schiller 2017). This kind of narrative may trump more realistic assessments of the worth of a given asset. If the narratives are not anchored in economic reality and realistic expectations, then the forming of the bubble may be described as a "collective rejection of reality" (Quigging 2010: p. 132). Bubbles on financial markets are defined as situations in which financial assets are systematically traded at prices far exceeding their fundamental value (Vogel 2010). An asset's fundamental value is the dividend expected in the long run if you were to keep it. If techshares, toxic mortgages and subprimes, or tulip bulbs are traded at prices above and beyond a realistic assessment of their worth, then the price has inflated artificially through speculation and no longer represents the underlying worth of whatever the asset being traded. If unaware of the fundamental value of an asset, investors might just end up paying far too high a price for very little or for nothing at all.

The same thing may happen in attention economy of the political sphere. The emergence of political bubbles on the attention market may also be described as a collective loss of reality. The political substance disappears ever more from the equation, just like an assets' fundamental value may do in financial bubbles. On the attention market, circulating stories are not just one of the reasons for the formation of bubbles. The stories themselves, or the events that reach the news agenda, are what may become bubbles. The characterization of financial bubbles may be transferred to attention economics by replacing:

- Asset with news item

- Price with amount of attention

- The fundamental value with political substance 
Thus, a political bubble is defined as a situation in which a political item gets a measure of attention in the media far exceeding what the political substance justifies.

\subsection{The Substance}

Citizens and journalists alike, as well as politicians (especially if they are under pressure), often call for political substance. Political substance concerns solving societal problems and improving social, economic, or cultural conditions in the long run. Politics is much about creating results; otherwise, it simply crumples to reality TV, horse races, and drama. The fundamental value of a political item - its political substance-may be established by its capacity to represent a societal problem. By being placed on the agenda, light may be shed upon it; it may be deliberated and acted upon. Trivially there are ideologically founded differences among various political parties pertaining to what should be considered societal problems and their order of priority. In Denmark, for instance, equality is seen as more of a problem by the left wing than by the right wing, and the opposite goes for high taxes. However, there is still quite a consensus that political issues such as unemployment, immigration, crime, and domestic violence are indeed social problems that need solving. These problems will not get solved politically, if the political debate loses its substance. If too much attention is spent on symbolic messages, signal policies, and debating for the sake of debacle without any potential of reaching concrete results, other than perhaps a further polarization of the political fronts. Swaths of the scarce attention in such cases go to political items with no actual content.

What is being debated and sucks all oxygen out of the public space in a political bubble is not, for instance, how best to solve integration problems or address the current refugee and immigration crisis. Rather, it is the sending of a signal to the public germane of who the sender is and where that per- 
son or party stands politically, if there were to be some who didn't know this already.

Political bubbles thrive particularly well in polarized opinion environments where the good story or the recognizable symbol gives easy and direct access to being for or against something: for or against the politics of Washington, for or against the EU, etc.

In these polarized opinion environments, you may also angle for a scandal and cash in on the opponents' anger. The angrier the other wing, the more sturdy and perhaps even vigorous you may seem to your followers. Thus, politicians may obtain an advantage from stimulating bubbles with spectacular, controversial, and provocative messages. Political bubbles may grant speculatively yield on the image and identity front, but not have much yield to society in terms of tangible political results, rather quite the contrary. The latter would require real political investment in substance, not speculating in the market of attention for political products.

\subsection{Investment and Speculation}

The British economist John Maynard Keynes (1883-1946) defined the difference between speculation and investment:

Investment is an activity that predicts an asset's return during its lifetime, whereas speculation is an activity that predicts the market's psychology. ${ }^{11}$

Financial investment involves assessing the fundamental value of assets, while speculation may ignore the value and play on the market. The return on an investment, however, also depends on various market fluctuations. Hence the dissociation between investment in the long run and speculation in the short run is not absolute. But that the difference

\footnotetext{
${ }^{11}$ Quoted from Peterson (2016).
} 
between investment and speculation is not absolute does not mean it is not there at all. Political investment embroils existing knowledge and information about a policy to try to assess its expected returns for society while determining the effects and side effects if the policies were to be carried out. If such assessment is not exercised, action is taken blindfolded. The fact that the future cannot be predicted exactly and in detail does not prevent the tooling of useful scenarios based on the current accessible evidence. Take climate models, for example:

These models are designed to provide scenarios of the future that can be used for guiding decisions about what policies to follow, such as how to reduce undesirable climate impacts and build resilience, and to plan for the future in the most cost-effective ways. Because human actions themselves are not predictable, these are not predictions, but rather they are called projections and depend on the nature of the "what-if" question. ${ }^{12}$

This argument goes for all the global challenges that the world faces, from climate and migration to online misinformation. Without acknowledging and using evidence, there will be no real solutions. If politics is to be more than show, speculating in attention and scandal and political entertainment with or without spin, it has to be informed by available evidence.

The same is true for the actual difficulties regarding receiving seekers of asylum, immigration, and integration of folk and fugitives. When professionalism, experience, and scientific evidence are replaced with symbolic politics coupled with the value of signals and speculation in attention, the fight against parallel societies, ghettoization, social control, radicalization, extremism, and terrorism hold only marginal chances of successful solutions.

\footnotetext{
${ }^{12}$ Trenberth, K. \& Knutti, R. (2017): "Yes, we can do 'sound' climate science even though it's projecting the future," The Conversation, April 5, 2017. Verified May 10, 2017: http://theconversation.com/ yes-we-can-do-sound-climate-science-even-though-its-projecting-thefuture-75763
} 
So how are we doing? Well, it sure is uphill. Evidence from anthropogenic global warming is not the only kind of evidence being called into question on political grounds; the weather itself gets contested. Not too long ago, it was turned into a political question whether the sun was shining or not on a special occasion.

Open Access This chapter is licensed under the terms of the Creative Commons Attribution 4.0 International License (http://creativecommons.org/licenses/by/4.0/), which permits use, sharing, adaptation, distribution and reproduction in any medium or format, as long as you give appropriate credit to the original author(s) and the source, provide a link to the Creative Commons license and indicate if changes were made.

The images or other third party material in this chapter are included in the chapter's Creative Commons license, unless indicated otherwise in a credit line to the material. If material is not included in the chapter's Creative Commons license and your intended use is not permitted by statutory regulation or exceeds the permitted use, you will need to obtain permission directly from the copyright holder.

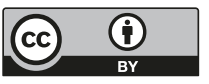

